\title{
EVALUATION OF ANTIANXIETY ACTIVITY OF BAUHINIA VARIEGATA IN MICE
}

\author{
Pragati Khare $^{1 *}$, Deepshikha ${ }^{2}$, Lubhan Singh ${ }^{3}$, Sweety $^{4}$, Shivani Chauhan ${ }^{5}$ and Ghanshyam Yadav $^{6}$ \\ *1 Department of Pharmacy, Shri Ram Murti Smarak (C.E.T), Bareilly, U.P., India. \\ 2,3,4,5,6 Meerut Institute of Engineering and Technology (Dept. of Pharmacy), Meerut, U.P., India.
}

*Corresponding Author: -

\begin{abstract}
: -
Bauhinia variegata has been used traditionally to treat bronchitis, leprosy and tumors. The present study was designed to evaluate the anti-anxiety activity of the leaves and seeds of Bauhinia variegata using elevated plus maze (EPM) model in Swiss albino mice. Albino mice were treated orally with different doses of the extracts (i.e. $100,200 \mathrm{mg} / \mathrm{kg}$ ) and behavior was observed on the EPM. Buspirone $(6 \mathrm{mg} / \mathrm{kg}, \mathrm{p.o})$ was used as a positive control. Results show that methanol extract at the dose of $100 \mathrm{mg} / \mathrm{kg}$ of the leaves of Bauhinia variegata and B. variegata seeds $(200 \mathrm{mg} / \mathrm{kg}) \mathrm{markedly}$ increased the average time spent in the open arms of the EPM. This effect was comparable to the effect produced by Buspirone. Hence this plant may be developed as a potentially useful anti-anxiety agent.
\end{abstract}

Keywords: - Anxiety, Bauhinia variegata, Buspirone, Elevated plus maze.

\section{(c) $(\$)$}




\section{INTRODUCTION}

Now-a-days the changed life style of the people and complexity of daily life in modern society leads to anxiety. In both developed and developing countries, mood and anxiety disorders are linked with chronic pain among medical patients ${ }^{11-}$ ${ }^{2]}$ (Evans et al, 2005 and Gureje et al, 1998). Benzodiazepines are the most widely used medicines for treating anxiety. But the use of benzodiazepines is associated with their adverse effects such as psychomotor impairment and dependence liability ${ }^{[3]}$ (Masoumeh et al, 2005). This has led to the investigation of plants which are traditionally used and alternate system of medicine for anxiety disorders and related diseases. ${ }^{[4]}$ (Spinella et al, 2001).

Bauhinia variegata (Caesalpiniaceae) also called Mountain Ebony (English), Rakta kanchan (Marathi), Kachnar (Hindi). It is a medium-sized, deciduous tree, found throughout India at an altitude of $1800 \mathrm{~m}$ in Himalayas ${ }^{[5]}$ (Patil et al, 2012). Bauhinia variegata Linn. is traditionally used in bronchitis, leprosy, and tumors, astringent, tonic, and anthelmintic ${ }^{[6,7]}$ (Ambasta, 1998 and Ram et al, 1980). So, the present study was done to evaluate the anti-anxiety activity of different extracts of Bauhinia variegata using the Elevated Plus Maze, an exteroceptive behavior animal model.

\section{Materials and Methods \\ Preparation of extracts}

The leaves of Bauhinia variegata were washed thoroughly in tap water, shade dried and powdered. This powder was packed into Soxhlet column and extracted with petroleum ether $\left(60-80^{\circ} \mathrm{C}\right)$ for $24 \mathrm{~h}$. The same marc was successively extracted with chloroform $\left(50-60^{\circ} \mathrm{C}\right)$ and later with ethanol $\left(68-78^{\circ} \mathrm{C}\right)$ for $24 \mathrm{~h}$. The extracts were concentrated on water bath $\left(50^{\circ} \mathrm{C}\right)$. After concentrated preparation, the dried powder extract was stored at room temperature. The yield of the petroleum extract, chloroform extract and methanolic extract were found to be $0.8 \%(\mathrm{w} / \mathrm{w}), 0.8 \%(\mathrm{w} / \mathrm{w})$ and $1.0 \%$ $(w / w)$ respectively. Methanolic extract was used for the experimental study.

\section{Test Animals}

Animals were procured from Central Animal House, MIET, Meerut. Animals were approved by Institutional Animal Ethic Committee (IAEC) of MIET, Meerut. Approval number (711/02/a/CPCSEA) was given for this work. The preferred rodent species included the mice.

Swiss Albino strain of young healthy adult of either sex animals in equal numbers per group $(n=6)$ were taken. At the commencement of the study the weight variations of animals used was kept minimal and not exceeded $\pm 20 \%$ of the mean weight of each animal. Normal weight of mice was 20-25 gm. The temperature of the experimental animal room was maintained to be $22^{\circ} \mathrm{C}\left( \pm 3^{\circ} \mathrm{C}\right)$. Relative humidity was maintained between $50-60 \%$. Lighting was artificial, the sequence being 12 hours light, 12 hours dark. For feeding, conventional laboratory diets were used with drinking aqueous supplied ad libitum. Animals of same group were caged together. Healthy young adult of either sex rats or mice were randomly assigned to the control, standard and treatment groups. The animals were identified uniquely (i.e., via marking at the base of the tail) and acclimatized for not less than 5 days in their cages prior to the start of the study.

\section{DRUGS \& CHEMICALS}

(a) Drugs: Buspirone was purchased from Sigma Aldrich.

(b) Chemicals: Methanol and ethanol were purchased from Central Drug House Laboratory (CDH).

(c) Analytical reagent grade chemicals were used in the study.

\section{VEHICLE}

$1 \%$ gum acacia.

\section{STUDY DESIGN}

The animals were selected randomly for each experiment and divided into 4 equal groups. Drugs (gum acacia, BVMEL, Buspirone) administered orally (p.o.) for $7 \& 14$ successive days as depicted in (Table 1)

Table 1: Protocol of the study

\begin{tabular}{|c|c|c|}
\hline Group & Drug & Dose \\
\hline I & Control (1\% gum acacia) & $(1.0 \mathrm{ml} / \mathrm{kg})$ \\
\hline II & BVMEL & $100 \mathrm{mg} / \mathrm{kg}$ \\
\hline III & BVMEL & $200 \mathrm{mg} / \mathrm{kg}$ \\
\hline IV & BVEES & $100 \mathrm{mg} / \mathrm{kg}$ \\
\hline V & BVEES & $200 \mathrm{mg} / \mathrm{kg}$ \\
\hline VI & Buspirone i.p. & $6 \mathrm{mg} / \mathrm{kg}$ \\
\hline
\end{tabular}

\section{Elevated plus maze model}

The wooden maze consisted of two open arms (length $50 \mathrm{~cm} \mathrm{X} \mathrm{breadth} 10 \mathrm{~cm}$ ) and two closed arms of the same size (height $40 \mathrm{~cm}$ ). The maze will be elevated to a height of $50 \mathrm{~cm}$ above the floor. Each animal will be tested initially in plus maze and, then, in bright and dark arena paradigm in a single setting. In acute study $60 \mathrm{~min}$ after and in chronic study $60 \mathrm{~min}$ after the last dose on the $10^{\text {th }}$ day of drug or vehicle administration, each animal will be placed in the centre 
square of the plus maze, facing one of the open arms. The number of entries into and the time spent in open and closed arms and the number of rears in each arm in a five-minute period will be noted. Following the elevated plus maze test, the animal will be placed at the centre of the brightly lit arena in the light and dark box. The number of entries into and the time spent in the bright arena, the number of rears in the bright and dark arenas and the duration of immobility will be noted ${ }^{[8]}$ (Gopala et al 2006).

\section{Statistical analysis}

The data will be expressed as Mean \pm SEM (standard error of Mean). Statistically difference between the groups will be analyzed by using one way analysis of variance (ANOVA) followed by student' $t$ ' test or Dunnett's test. The results will be considered statistically significant if $p<0.05$.

\section{Results}

The results obtained from the EPM model, indicates that methanolic extract showed significant $(\mathrm{p}<0.05)$ anti anxiety activity as compared to buspirone. The average time spent in open arms increased from $6.772 \pm 0.773$ (sec) in control to $23.958 \pm 1.087(\mathrm{sec})$ in methanolic extract at a dose of $100 \mathrm{mg} / \mathrm{kg}$. Results obtained are presented in Table 1 .

\section{Elevated Plus Maze test}

Table 1. Effect of leaves and seeds of $B$. variegata Linn in case of elevated plus maze test in mice, after 14 days of treatment.

\begin{tabular}{|c|c|c|c|c|c|c|c|c|}
\hline \multirow[t]{2}{*}{ S.No. } & \multirow[t]{2}{*}{ Treatment } & \multirow{2}{*}{$\begin{array}{c}\text { Dose } \\
(\mathrm{mg} / \mathrm{kg})\end{array}$} & \multicolumn{2}{|c|}{ No. of entries (counts/5min) } & \multicolumn{4}{|c|}{ Time spent (s/5 min) } \\
\hline & & & Open arms & Closed arms & Open arms & & Closed arms & \\
\hline 1. & $\left(\begin{array}{c}\text { Control } \\
\text { acacia) }\end{array}\right.$ & $10.0 \mathrm{ml} / \mathrm{kg}$ & $2 \pm 0.527$ & $12.5 \pm 1.504$ & $\begin{array}{r}59.333 \\
7.830\end{array}$ & & $\begin{array}{r}234.333 \\
6.530\end{array}$ & \pm \\
\hline 2. & BVMEL & 100 & $\begin{array}{l}6.666 \pm \\
1.367 *\end{array}$ & $\begin{array}{l}6.833 \\
0.863 *\end{array}$ & \pm 106 6.168*** & & $\begin{array}{r}194.66 \\
5.630 * *\end{array}$ & \pm \\
\hline 3. & BVMEL & 200 & $4.5 \pm 0.993$ & $\begin{array}{ll}10.666 & \\
& \\
& =\end{array}$ & $\begin{array}{c}69.833 \\
6.215\end{array}$ & \pm & $\begin{array}{c}224.666 \\
11.376\end{array}$ & \pm \\
\hline 4. & BVEES & 100 & $\begin{array}{c}1.833 \pm \\
0.723\end{array}$ & $\begin{array}{rr}12.166 & \\
& 1.754\end{array}$ & $\begin{array}{l}80.166 \\
13.855\end{array}$ & \pm & $\begin{array}{r}216.66 \\
\pm 7.7483 \\
\end{array}$ & \\
\hline 5. & BVEES & 200 & $6.5 \pm 1.219 *$ & $7.5 \pm 0.697^{*}$ & $\begin{array}{l}95.666 \\
4.568^{*}\end{array}$ & & $\begin{array}{l}200.166 \\
7.406 *\end{array}$ & \pm \\
\hline 6. & $\begin{array}{l}\text { Buspirone } \\
\text { i.p. }\end{array}$ & 6 & $1.020 * *$ & \pm 5.833 $0.863 * *$ & $\begin{array}{c}141.833 \\
2.722 * * *\end{array}$ & \pm & $\begin{array}{c}151.66 \\
8.047 * * *\end{array}$ & \pm \\
\hline
\end{tabular}

Result are expressed as MEAN $\pm \operatorname{SEM}(\mathrm{n}=6), * \mathrm{P}<0.05, * * \mathrm{P}<0.01, * * * \mathrm{P}<0.001$ and $\mathrm{ns}=$ not significant; when compared to control group by one way ANOVA followed by Dunnett's test.

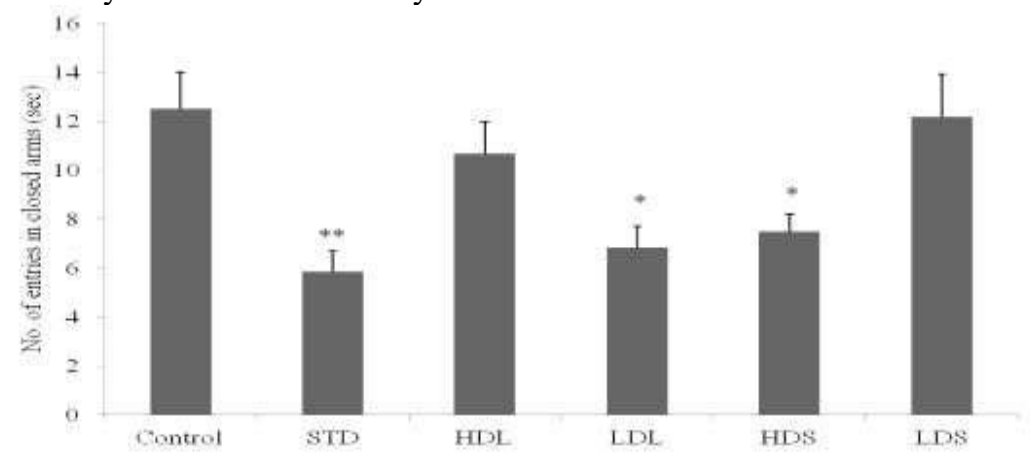

Fig. 1: Effect of B.variegata Linn on no. of entries in closed arms (sec).

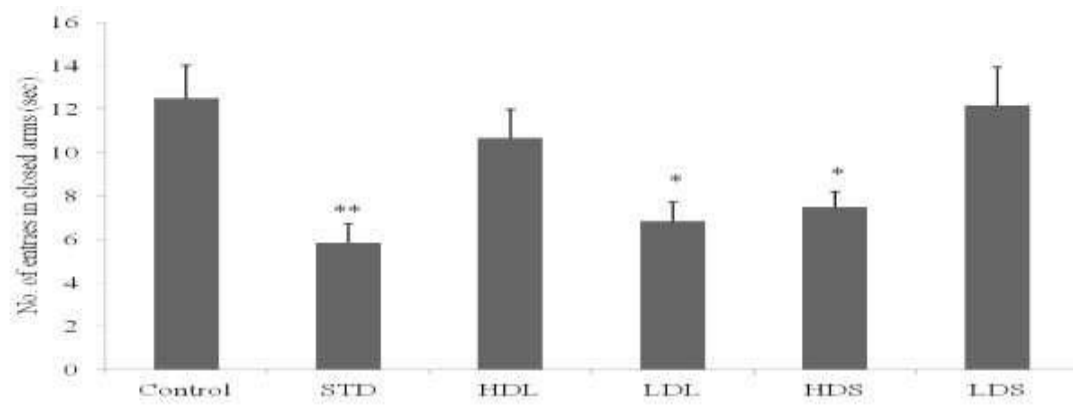

Fig. 2: Effect of B. variegata Linn on no. of entries in open arms (sec). 


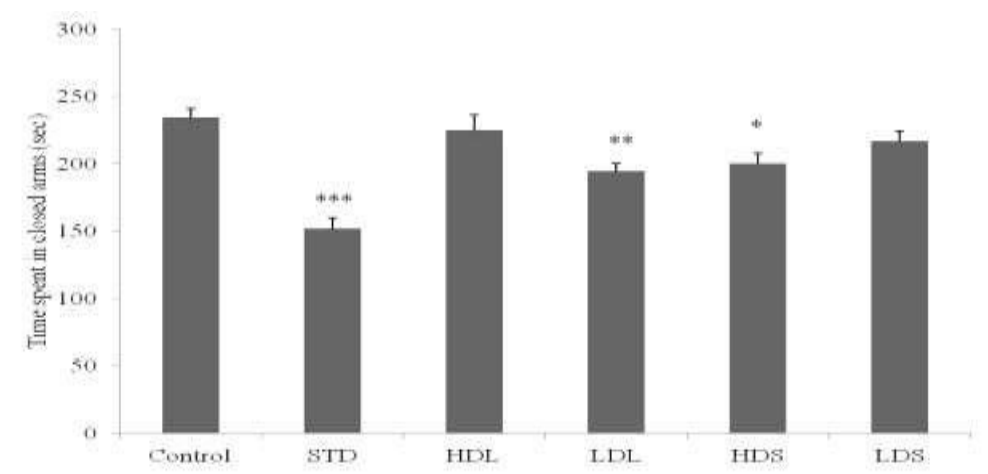

Fig. 3: Effect of B. variegata Linn on time spent in closed arms (sec).

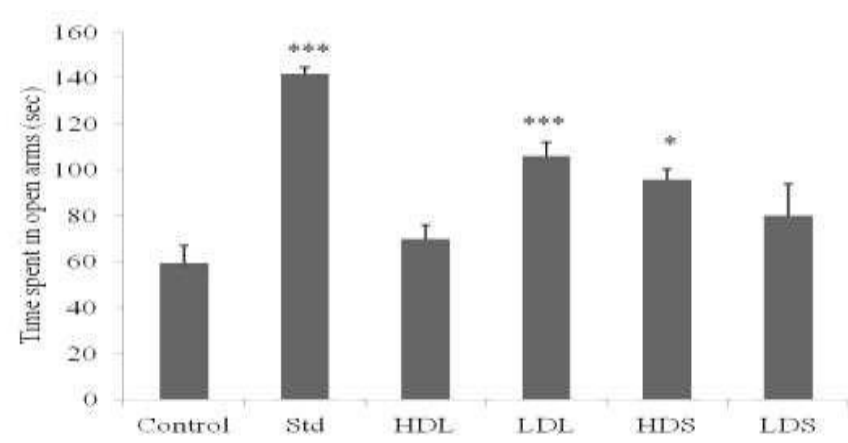

Fig. 4: Effect of B.variegata Linn on time spent in open arms (sec).

\section{Discussion}

The EPM model was chosen as it is effective, cheap, and simple, less time consuming, requires no preliminary training to the mice and does not cause much discomfort to the animals while handling. The model is principally based on the observations that the exposure of animals to an elevated and open maze results in approach-avoidance conflict which is manifested as an exploratory-cum-fear drive. When the animals are placed on the EPM then anxiety is induced by the fear due to height. In animals, the anxiety is indicated by reduction in the motor activity and their reliability to remain at safer places. Antianxiety drugs act by enhancing the motor activity which is indicated by the time spent by the animal in the open arms ${ }^{[9-10]}$ (Kumar et al, 2005 and Gupta et al, 2010).

The light dark transition model box is also widely used for rodents as a model for screening anxiolytic or anxiogenic drugs. A good agreement has been observed between relative potency of drugs clinically used in the treatment of anxiety in humans and their ability to facilitate exploratory activity in the light/dark paradigm in mice.

The present data showed that B. variegata leaves $(100 \mathrm{mg} / \mathrm{kg})$ and $B$. variegata seeds $(200 \mathrm{mg} / \mathrm{kg})$ could increase the time spent in the light area, suggesting again these fractions possesses anxiolytic properties. The anxiolytic effects of methanolic extract of B.variegata may be related to their flavonoid content. Flavonoids with anxiolytic activity have been described in many plant species used in folk medicine such as Passiflora coerulea ${ }^{[11]}$ (Wolfman et al, 1994). This effect has been attributed to the affinity of flavonoids for the central benzodiazepine receptors ${ }^{[12-14]}$ (Medina et al, 1997, Griebel et al, 1999 and Paladini et al, 1999). However, further studies are required to identify the phytoconstituent responsible for the anxiolytic mechanism.

\section{References}

[1].Evans, D.L., Charney, D.S., Lewis, L., Golden, J.M., Krishnan, K.R.R. and Nemeroff C.B. 2005. Mood disorders in the medically ill: Scientific review and recommendations, Biol. Psychiatry, vol. 58, 175-189.

[2].Gureje, O., Von, Korff, M., Simon, G.E. and Gater, R., 1998. Persistent pain and well-being: A World Health Organization study in primary care, JAMA, vol. 280, 147-151.

[3].Masoumeh, E., Mohammad, K. and Maryam, F.A., 2005. Coriandrum sativum: evaluation of its anxiolytic effect in the elevated plus-maze, J. Ethnopharmacol., vol. 96, 365-370.

[4].Spinella, M., 2001. Herbal Medicines and Epilepsy: The Potential for Benefit and Adverse Effects, Epilepsy Behav., vol. 2, 524-532.

[5].Patil, J. K., Patel, M. R., Sayyed, H. Y. et al, 2012. Pharmacognostic and phytochemical investigation of Bauhinia variegata (linn.) Benth. Stem bark. Pharma science monitor, vol. 3(1), 1-12.

[6].Ambasta, S.P., 1998. The wealth of India, Raw materials, vol. 2, 56-7.

[7].Ram, P.R., Mehrotra, B.N., 1980. In: Compendium of Indian medicinal plants, vol. 3, 84-91.

[8].Gopala Krishna, H.N., Sangha, R.B., et al. 2006. Anti-anxiety activity of NR-ANX-C, polyherbal preparation in rats. Indian Journal of Pharmacology vol. 38, 330-335.

[9].Kumar, S. and Sharma, A., 2005. Anti-anxiety activity studies of various extracts of Turnera aphrodisiaca Ward., J. Herb. Pharmacother., vol. 5, 13-21. 
[10]. Gupta, V., Bansal, P., Niazi, J., Kaur, G., 2010. Anti-anxiety Activity of Citrus paradisi var.

[11]. star ruby Extracts, International Journal of PharmTech Research, vol.2 (3), 1655-1657.

[12]. Wolfman, C., Viola, H., Paladini, A., Dajas, F. and Medina, J.H., 1994. Possible anxiolytic effects of chrysin, a central benzodiazepine receptor ligand isolated from Passiflora coerulea, Pharmacol. Biochem. Behav., vol. 47, 1 4.

[13]. Medina J.H., Viola H., Wolfman C., Marder M., Wasowski C., Clavo D. and Paladini A.C., Neuroactive flavonoids: new ligands for the benzodiazepine receptors, Phytomed., 1997, 5, 235243.

[14]. Griebel G., Perrault G., Tan S., Schoemaker H. and Sanger D.J., Pharmacological studies on synthetic flavonoids: comparison with diazepam, Neuropharmacol., 1999, 38, 965.

[15]. Paladini A.C., Marder M., Viola H., Wolfman C., Wasowski C. and Medina J.H., Flavonoids and the central nervous system: from forgotten factors to potent anxiolytic compounds, J. Pharm. Pharmacol., 1999, 51, 519-526. 